\title{
Model Loyalitas Merek pada Teh Kemasan di Indonesia
}

\author{
Received: \\ 8 Agustus 2020 \\ Revision \\ received: \\ 15 Agustus 2020 \\ Wahyu Rafdinal*1, Yuliarni Putri ${ }^{2}$ dan Fitria Ridhaningsih ${ }^{2}$ \\ ${ }^{1}$ Jurusan Administrasi Niaga, Politeknik Negeri Bandung, Indonesia \\ ${ }^{2}$ Jurusan Manajemen, Universitas Taman Siswa, Indonesia
}

Accepted:

24 Agustus 2020

\begin{abstract}
:
Packaged tea drinks is one of the most widely consumed beverage products by Indonesians. Currently, many packaged tea drinks compete in the market, which makes companies need to think about the right strategy to gain brand loyalty. The scope of this research is the influence of brand awareness, brand image, customer value and satisfaction on brand loyalty. The sample in this study were 200 respondents. The data analysis technique used is the Structure Equation Model (SEM). The results showed that satisfaction has a significant effect on brand loyalty. Satisfaction mediates the influence of customer value and brand image on brand lotality. Customer value and brand image have a significant effect on satisfaction. Then, brand awareness affects the brand image. The results of this study prove the important role of satisfaction in increasing brand loyalty. In addition, customer value and brand image also play a role in increasing satisfaction. The beginning of these influences is brand awareness. The results of this study provide knowledge that satisfaction, customer value, brand image, and brand awareness are important factors in influencing brand loyalty of packaged tea drinks.
\end{abstract}

Keywords: brand awareness, brand image, customer value, satisfaction, brand loyalty.

\begin{abstract}
Abstrak:
Teh kemasan merupakan salah satu produk minuman yang paling banyak dikonsumsi oleh masyarakat indonesia. Saat ini, banyak produk teh kemasan bersaing di pasaran yang membuat perusahaan perlu memikirkan strategi yang tepat untuk mandapatkan loyalitas merek. Ruang lingkup penelitian ini adalah pengaruh kesadaran merek, citra merek, nilai pelanggan dan kepuasan terhadap loyalitas merek. Sampel dalam penelitian ini sebanyak 200 responden. Teknik analisis data yang digunakan yaitu Structure Equation Model (SEM). Hasil penelitian menunjukan bahwa kepuasan berpengaruh signifikan terhadap loyalitas merek. Kepuasan memediasi pengaruh nilai pelanggan dan citra merek terhadap lotalitas merek. Nilai pelanggan dan citra merek berpengaruh signifikan terhadap kepuasan. Kemudian, kesadaran merek berpengaruh terhadap citra merek. Hasil penelitian ini membuktikan peran penting kepuasan dalam meningkatkan loyalitas merek. Selain itu, nilai pelanggan dan citra merek juga memberikan peran dalam meningkatkan kepuasan. Awal dari pengaruh-pengaruh tersebut adalah kesadaran merek. Hasil penelitian ini memberikan pengetahuan bahwa kepuasan, nilai pelanggan, citra merek, dan kesadaran merek merupakan factor penting dalam mempengaruhi loyalitas merek khususnya pada produk the kemasan.
\end{abstract}

Kata kunci: kesadaran merek, citra merek, nilai pelanggan, kepuasan, loyalitas merek.

\section{Pendahuluan}

Kebiasaan minum teh sudah merupakan kebiasaan masyarakat Indonesia semenjak zaman dahulu. Hal itu dikarenakan Negara Indonesia merupakan salah satu penghasil teh terbaik di dunia. Kebiasaan 
minum teh ini meliputi hampir seluruh kelompok usia, dari usia remaja, dewasa bahkan para pemula. Kebiasaan masyarakat indonesia dalam menikmati teh dengan waktu yang tidak terbatas, baik pagi, siang, sore, maupun malam hari. Hal tersebut memberikan peluang besar bagi produsen untuk berlomba-lomba memproduksi dan menawarkan minuman teh dalam kemasan yang siap untuk diminum/Ready to drink (RTD). Dengan adanya minuman teh instan dalam kemasan sekarang ini, pelanggan tidak bersusah payah membuat teh karena sudah banyak minuman teh dalam kemasan yang tersedia dengan berbagai merek sesuai selera dan keinginan pelanggan.

Dalam upaya untuk menciptakan pelanggan, hal yang perlu diperhatikan juga adalah bagaimana suatu perusahaan dapat menciptakan loyalitas merek yang kuat terhadap merek produk yang ditawarkan oleh perusahaan. Dalam menciptakan loyalitas merek, tentu ada faktor lain yang mendukung agar loyalitas merek yang tercipta sesuai dengan tujuan perusahaan. Faktor-faktor tesebut merupakan variabel dalam peneitian ini. Variabel tersebut diantaranya, kesadaran merek, citra merek, nilai pelanggan dan kepuasan. Dalam penelitian Kocoglu et al., (2015) menyatakan bahwa terdapat hubungan yang positif antara kesadaran merek dan loyalitas merek. Pelanggan yang memiliki kesadaran merek terhadap suatu merek akan meningkatkan loyalitas merek pelanggan terhadap merek yang ditawarkan. Selin itu, Mao (2010) menyatakan bahwa loyalitas merek dipengaruhi oleh kesadaran merek dan citra merek. Dalam mendukung strategi loyalitas merek, maka perusahaan harus memperhatikan kesadaran pelanggan terhadap merek, dan menciptakan citra merek produk sehingga terciptanya pelanggan yang benar-benar loyal terhadap suatu merek yang ditawarkan. Selain itu, kepuasan juga memegang peran penting dalam meningkatkan loyalitas merek (Jorfi \& Gayem, 2016). Kepuasan dan loyalitas pelanggan dapat dicapai dengan menekankan produk atau mereknya (Martisiute et al., 2010). Dengan demikian dapat dinyatakan bahwa loyalitas merek dapat dipengaruhi oleh kesadaran merek, citra merek, nilai pelanggan dan kepuasan.

Melihat persaingan perusahaan, tentunya pelanggan sekarang menghadapi banyak pilihan produk. Untuk produk minuman teh siap minum (RTD) sangat banyak merek produk teh kemasan siap minum yang ditawarkan. Pesaingan antara perusahaan yang memproduksi minuman teh kemasan siap saji sangat terlihat jelas. Berdasarkan data top brand indeks 2019 menunjukan bahwa Teh Pucuk Harum memperoleh indeks 35.2\%, Teh Botol Sosro 21.2\%, Teh Gelas 13.8\%, Frestea 8.5\%, dan Mountea 3.7\% (Award, 2019). Hasil tersebut menunjukan bahwa brand teh tersebut sudah lebih dulu dikenal oleh pelanggan. Meskipun perolehan top brand index merek teh tersebut sudah terbilang tinggi dan memperoleh peringkat TOP, namun perusahaan perlu mengetahui dan menganalisis apakah merek teh mereka sudah memiliki kesadaran merek yang kuat dan melekat dibenak konsumen. Apakah sudah memiliki citra merek yang kuat, serta bagaimana nilai pelanggan yang positif dapat menciptakan kepuasan dan meningkatkan loyalitas merek.

Berdasarkan Latar belakang masalah diatas maka penulis tertarik melalukan penelitian mengenai kesadaran merek, citra merek, nilai pelanggan, kepuasan dan loyalitas merek. Penelitian terdahulu menjelaskan bahwa variabel kesadaran merek, citra merek, nilai pelanggan, kepuasan dan loyalitas merek memiliki hubungan yang positif. Hasil penelitian ini memberikan pengetahuan penting dalam membentuk loyalitas merek pada produk teh di Indonesia.

\section{Kajian Literatur}

\section{Loyalitas Merek}

Loyalitas merek merupakan kunci untuk mencapai kesuksesan strategis (Aaker, 2013). Loyalitas merek adalah keinginan untuk melakukan dan perilaku pembelian ulang (Peter \& Olson, 2000). Mowen \& Minor (2002) mendefinisikan loyalitas merek sebagai seajuhmana seorang pelanggan menunnjukkan sikap positif terhadap suatu merek, mempunyai komitmen pada merek tertentu, dan berniat untuk membelinya dimasa depan. Menurut Aaker (2013) loyalitas merek atau ketahanan untuk mengganti merek, dapat didasarkan pada kebiasaan sederhana, preferensi, atau biaya untuk mengganti merek. Loyalitas merek dipengaruhi secara langsung oleh kepuasan/dan ketidakpuasan dengan merek yang telah diakumulasi dalam jangka waktu tertentu sebagaimana persepsi kualitas produk. Karena empat sampai enam kali lebih mudah untuk mempertahankan pelanggan lama dari pada memperoleh 
yang baru, maka para manajer harus memberi prioritas tertinggi pada penciptaan strategi yang membangun dan mempertahankan loyalitas merek.

\section{Kesadaran Merek dan Citra Merek}

Kesadaran merek berfungsi untuk mendiferensiasikan merek bersama dimensi yang diingat kembali (Aaker, 2013). Pelanggan akan menyadari adanya suatu merek atau mengingat merek dari berbagai atribut-atribut merek seperti slogan, Iklan, Logo dan atribut merek lainnya. Setelah pelanggan mampu mengingat merek, maka pelanggan akan mempersepsikan merek tersebut. Esch et al. (2006) menyatakan bahwa kesadaran merek sangat penting untuk membentuk citra merek, karena jika brand sudah mapan di ingatan pelanggan maka lebih mudah untuk menciptakan asosiasi asosiasi merek. Penelitian lainnya mengatakan bahwa kesadaran merek berpengaruh terhadap citra merek (Mulyono, 2016). Terdapat hubungan yang positif antara kesadaran merek dengan citra merek sehingga hipotesis yang diajukan sebagi berikut.

H1. Kesadaran merek berpengaruh signifikan dan positif terhadap citra merek

\section{Citra Merek dan Nilai Pelanggan}

Citra merek merupakan seperangkat asosiasi yang diciptkan atau dipelihara oleh pemasar. Sedangkan nilai pelanggan merupakan preferensi konseptual dan evaluasi pelanggan terhadap atribut merek, kinerja produk dan konsekuensi yang timbul dari pemakaian produk. Jika suatu perusahaan menjanjikan sebuah merek yang sesuai dengan harapan pelanggan maka akan menumbuhkan nilai pelanggan yang positif. Hubungan citra merek dengan nilai pelanggan ini juga dikemukakan oleh Glynn \& Woodside (2009) yang mengatakan bahwa nilai pelanggan dipengaruhi oleh citra merek. Penelitian terdahulu juga menyatakan bahwa citra merek dan nilai pelanggan berpengaruh postif dan signifikan (Rahi, 2016).

H2. Citra merek berpengaruh signifikan dan positif terhadap nilai pelanggan

\section{Citra Merek dan Kepuasan}

Hubungan antara citra merek dan kepuasan juga dinyatakan oleh Shahroudi \& Naimi (2014) yang mengatakan bahwa citra merek berpengaruh positif dan signifikan terhadap kepuasan pelanggan. Citra merek sangat mendukung kepuasan pelanggan akan merek produk teh. Hubungan citra merek dan kepuasan ini juga diperkuat oleh Dunuwille \& Pathmini (2016) yang mengatakan bahwa citra merek dan kepuasan pelanggan memiliki hubungan yang positif. Sehingga dapat disimpulkan bahwa untuk meningkatkan kepuasan pelanggan dibutuhkan citra merek yang positif. Jika produk teh memiliki citra merek yang positif maka secara langsung pelanggan akan merasa puas.

H3. Citra merek berpengaruh signifikan dan positif terhadap kepuasan

\section{Nilai Pelanggan dan Kepuasan}

Nilai pelanggan adalah preferensi konseptual konseptual atau evaluasi pelanggan terhadap atribut produk, kinerja produk dan konsekuensi yang didapatkan pada pemakaian produk yang memfasilitasi pencapaian tujuan dan sasaran pelanggan dalam situasi pemakaian. Sedangkan kepuasan adalah semacam penilaian perilaku yang terjadi setelah pengalaman mengkonsumsi layanan (Christopher Lovelock, 2012). Jika nilai pelanggan yang diterima sesuai dengan yang diaharapkannya maka pelanggan akan merasa puas. Hubungan antara nilai pelanggan dan kepuasan ini juga dinyatakan oleh Ariff et al. (2012) yang mengatakan bahwa nilai yang dirasakan pelanggan berpengaruh terhadap kepuasan pelanggan. Jika pelanggan merasakan nilai yang positif dari suatu merek maka pelanggan akan merasa puas dengan merek tersebut begitu juga sebaliknya. Onaran et al. (2013) mengatakan bahwa nilai pelanggan berpengaruh langsung terhadap kepuasan pelanggan.

H4. Nilai pelanggan berpengaruh signifikan dan positif terhadap kepuasan

\section{Kepuasan dan Loyalitas Merek}

Kepuasan dan loyalitas adalah dua tahap dalam respon pelanggan terhadap penawaran perusahaan. Kepuasan adalah tahap awal dalam respon pelanggan terhadap penawaran perusahaan sedangkan loyalitas adalah tahap matang dalam respon seperti itu (Torres-Moraga et al., 2008). Dalam penelitian Martisiute et al. (2010) mengatakan bahwa Kepuasan dan loyalitas pelanggan dapat dicapai dengan 
menekankan produk atau mereknya, kepuasan pelanggan sangat penting untuk loyalitas pelanggan. Kesetiaan dan kepuasan memiliki hubungan yang kuat.

Menurut Tu \& Chang (2012) mengatakan bahwa kepuasan pelanggan berepngaruh terhadap loyalitas pelanggan. Pendapat lain mengatakan bahwa kepuasan berpengaruh langsung terhadap loyalitas merek (Mulyono, 2016). Sedangkan pendapat lain juga mengatakan bahwa Loyalitas merek dipengaruhi oleh kepuasan pelanggan (Mao, 2010). Jorfi \& Gayem (2016) mengatakan bahwa kepuasan pelanggan berpengaruh positif tehadap loyalitas merek. Sehingga dapat disimpulkan bahwa loyalitas merek dipengaruhi oleh kepuasan pelanggan. Jika pelanggan puas dengan merek produk teh, maka loyalitas merek akan semakin meningkat. Sangat perlu memperhatikan kepuasan pelanggan agar terciptanya tujuan perusahaan yaitu menciptakan loyalitas merek.

H5. Kepuasan berpengaruh signifikan dan positif terhadap loyalitas merek

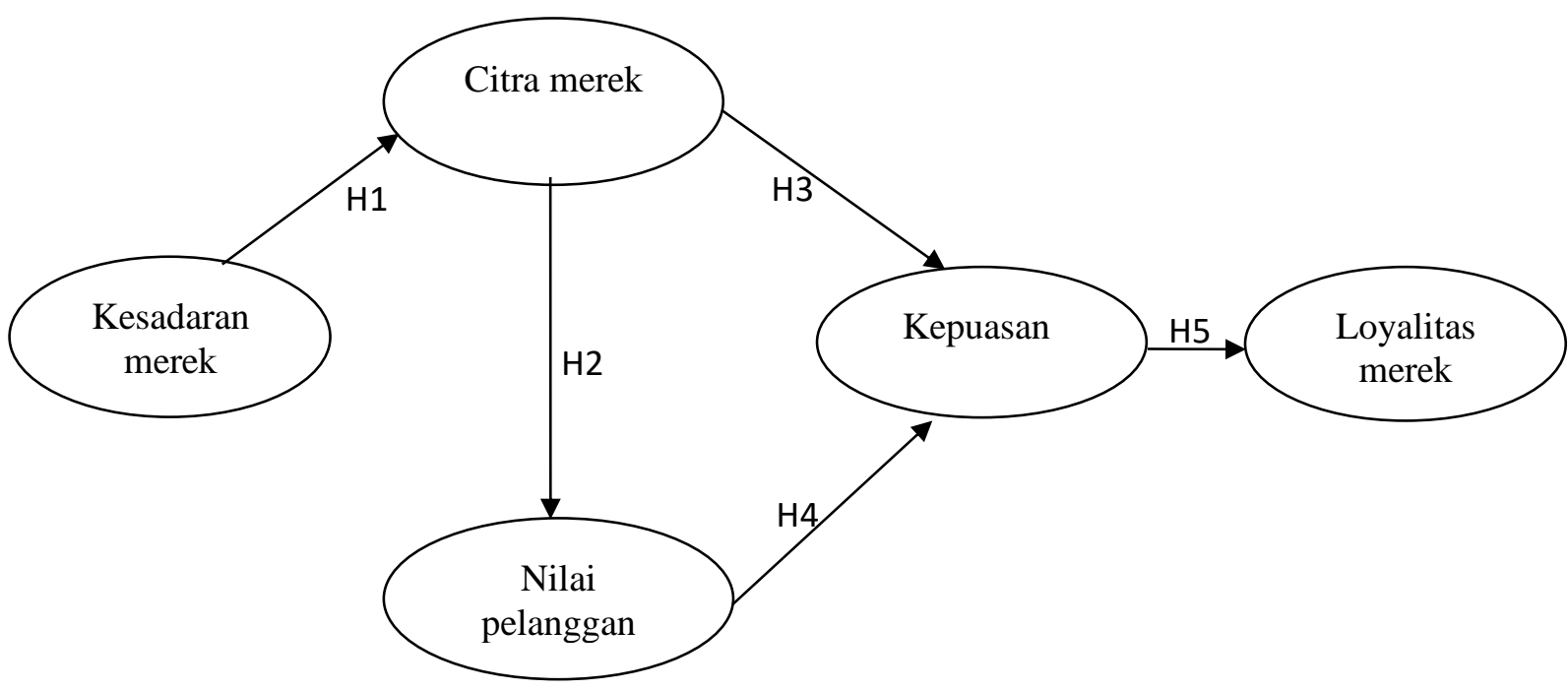

Gambar 1. Kerangka Konseptual

\section{Metode Penelitian}

\section{Pengumpulan Data}

Dalam mengevaluasi model penelitian, data empiris dikumpulkan melalui kuesioner survei dan kemudian dinilai menggunakan structure equation model. Kuesioner disebarkan melalui survei online kepada konsumen produk teh kemasan yang tersebar di berbagai wilayah di Indonesia. Kuesioner dibagi menjadi dua bagian. Pertama, karakteristik responden seperti jenis kelamin, pendapatan, usia, dan pekerjaan. Kedua, komponen utama kuisioner adalah instrumen variabel penelitian. Setiap item diukur menggunakan skala Likert 5 poin. Sebanyak 200 tanggapan diperoleh dari survei tersebut.

\section{Sampel}

Kuisioner dibagikan konsumen teh kemasan melalui survei online. Mereka diundang dengan baik untuk berpartisipasi dalam survei online ini. Sebelum dilakukan pendataan, responden dalam penelitian ini telah menyatakan bersedia memberikan data yang sebenarnya. Setelah menganalisis hasil survei, analisis statistik deskriptif digunakan untuk menganalisis karakteristik demografi dasar responden. Berdasarkan hasil penyebaran kuesioner kepada 200 responden, demografi responden ditunjukkan pada Tabel 1.

Tabel 1. Demografi responden

\begin{tabular}{|l|l|l|l|}
\hline Variabel & Deskripsi & Frekuensi (orang) & Persentase (\%) \\
\hline \multirow{3}{*}{ Jenis Kelamin } & Laki-laki & 111 & 55.5 \\
\cline { 2 - 4 } & Perempuan & 89 & 44.5 \\
\hline \multirow{2}{*}{ Usia } & $17-25$ tahun & 86 & 43 \\
\cline { 2 - 4 } & $26-35$ tahun & 91 & 44,5 \\
\hline
\end{tabular}




\begin{tabular}{|l|l|l|l|}
\hline & $>46$ tahun & 23 & 11,5 \\
\hline \multirow{5}{*}{ Pendidikan Terakhir } & SD & 14 & 7 \\
\cline { 2 - 4 } & SMP & 35 & 17,5 \\
\cline { 2 - 4 } & SMA & 83 & 41,5 \\
\cline { 2 - 4 } & S1 & 43 & 21,5 \\
\cline { 2 - 4 } & S2 & 25 & 12,5 \\
\hline \multirow{5}{*}{ Pekerjaan } & PNS & 21 & 10,5 \\
\cline { 2 - 4 } & Pelajar/Mahasiswa & 53 & 26,5 \\
\cline { 2 - 4 } & Pegawai swasta & 79 & 39,5 \\
\cline { 2 - 4 } & Pedagang & 37 & 18,5 \\
\cline { 2 - 4 } & Lainnya & 10 & 5 \\
\hline
\end{tabular}

\section{Pengukuran}

Berdasarkan model penelitian yang diusulkan, lima konstruksi utama diukur dengan beberapa item. Item ini diadopsi atau diadaptasi dari literatur yang ada yang ditampilkan pada table berikut:

Tabel 2. Pengukuran

\begin{tabular}{|c|c|c|}
\hline Variabel & Item pernyataan & Sumber \\
\hline $\begin{array}{l}\text { Loyalitas } \\
\text { merek }(Y)\end{array}$ & $\begin{array}{l}\text { 1. Saya akan membeli teh kemasan "x" } \\
\text { 2. Teh kemasan "x" selalu menjadi pilihan yang utama } \\
\text { dibandingkan merek lain } \\
\text { 3. Merekomendasikan teh "x" kepada orang lain } \\
\text { 4. Memberikan informasi yang positif kepada orang lain } \\
\text { 5. Selalu mengkonsumsi teh kemasan "x". }\end{array}$ & (Suki \& Sasmita, 2015) \\
\hline $\begin{array}{l}\text { Kesadaran } \\
\text { merek (X1) }\end{array}$ & $\begin{array}{l}\text { 1. Saya mampu mengingat dengan cepat merek teh "x" } \\
\text { melalui symbol atau logo } \\
\text { 2. Saya mampu mengenal merek "x" tertentu melalui } \\
\text { iklan } \\
\text { 3. Merek teh " } x " \text { sudah ada dalam ingatan saya } \\
\text { 4. Saya sudah lama menyadari merek teh" } x " \\
\text { 5. Merek teh "x" yang pertama kali muncul dalam } \\
\text { ingatan saya }\end{array}$ & (Suki \& Sasmita, 2015) \\
\hline $\begin{array}{l}\text { Citra merek } \\
\text { (X2) }\end{array}$ & $\begin{array}{l}\text { 1. Merek teh "x" merupakan merek yang sudah mapan } \\
\text { 2. Teh "x" memiliki citra merek yang positif } \\
\text { 3. Merek Teh "x" memiliki citra yang berebeda } \\
\text { dibandingkan pesaing }\end{array}$ & (Suki \& Sasmita, 2015) \\
\hline $\begin{array}{l}\text { Nilai } \\
\text { pelanggan } \\
\text { (X3) }\end{array}$ & $\begin{array}{l}\text { 1. Harga Teh "x" Sangat ekonomis } \\
\text { 2. Teh "x" merupakan minuman dengan kualitas teh } \\
\text { terbaik } \\
\text { 3. Teh "x" memberikan banyak manfaat } \\
\text { 4. Manfaat Teh "x"sesuai dengan yang saya harapkan. }\end{array}$ & $\begin{array}{l}\text { (Hanzaee \& Norouzi, } \\
\text { 2012) }\end{array}$ \\
\hline $\begin{array}{l}\text { Kepuasan } \\
\text { (M) }\end{array}$ & $\begin{array}{l}\text { 1. Saya merasa puas dengan keputusan saya untuk } \\
\text { mengkonsumsi Teh "x" } \\
\text { 2. Meskipun banyak pilihan merek lain, saya tetap } \\
\text { memilih teh "x" } \\
\text { 3. Mengkonsumsi teh "x" merupakan pilihan terbaik } \\
\text { saya } \\
\text { 4. Keputusan saya mebeli Teh "x" menbuat saya merasa } \\
\text { senang } \\
\text { 5. Saya merasa senang pada saat mengkonsumsi Teh } \\
\text { "x" }\end{array}$ & (Hasan et al., 2008) \\
\hline
\end{tabular}




\section{Hasil dan Pembahasan}

\section{Reliabilitas dan Validitas}

Sebelum analisis data, instrumen pengukuran dievaluasi keandalannya. Ini dilakukan untuk menentukan sejauh mana variabel yang diamati mengukur nilai, dan apakah 'bebas dari kesalahan. Jadi, konstruksi diuji reliabilitasnya, menggunakan uji Cronbach alpha. Nunnally (1978) menyarankan bahwa skor untuk setiap konstruk harus lebih besar dari 0,6 agar dapat dianggap reliabel. Seperti yang ditunjukkan pada Tabel 3, Cronbach alpha (reliabilitas) berkisar antara 0,724 sampai 0,770. Karena reliabilitas keseluruhan pengukuran di atas 0,7 , instrumen pengukuran terbukti memiliki konsistensi internal yang cukup. Hasilnya, data dianggap sesuai untuk analisis lebih lanjut. Kemudian, dalam menentukan uji validitas, Hair et al. (1998) menentukan loading minimal yang diperlukan untuk memasukkan item dalam konstruksinya masing-masing, variabel dengan loading lebih besar dari 0,5 cukup signifikan. Jadi, penelitian ini menerima item dengan loading 0,5 atau lebih besar.

Tabel 3. Reliabilitas dan validitas

\begin{tabular}{|c|c|c|c|}
\hline \multicolumn{2}{|c|}{ Hubungan antar konstruk } & Loading factor & \multirow{6}{*}{$\begin{array}{l}\text { Cronbach alpha } \\
0.724\end{array}$} \\
\hline \multirow[t]{5}{*}{ Loyalitas merek } & $\rightarrow \quad$ BL1 & 0.547 & \\
\hline & $\rightarrow \quad$ BL2 & 0.637 & \\
\hline & $\rightarrow \quad$ BL3 & 0.640 & \\
\hline & $\rightarrow \quad$ BL4 & 0.638 & \\
\hline & $\rightarrow \quad$ BL5 & 0.567 & \\
\hline \multirow[t]{5}{*}{ Kesadaran merek } & $\rightarrow \quad \mathrm{BA} 1$ & 0.629 & \multirow[t]{5}{*}{0.744} \\
\hline & $\rightarrow \quad \mathrm{BA} 2$ & 0.556 & \\
\hline & $\rightarrow \quad \mathrm{BA} 3$ & 0.611 & \\
\hline & $\rightarrow \quad \mathrm{BA} 4$ & 0.595 & \\
\hline & $\rightarrow \quad$ BA5 & 0.611 & \\
\hline \multirow[t]{3}{*}{ Citra merek } & $\rightarrow \mathrm{BI} 1$ & 0.590 & \multirow[t]{3}{*}{0.722} \\
\hline & $\rightarrow \quad \mathrm{BI} 2$ & 0.621 & \\
\hline & $\rightarrow \quad \mathrm{BI} 3$ & 0.604 & \\
\hline \multirow[t]{4}{*}{ Nilai pelanggan } & $\rightarrow \quad \mathrm{CV} 1$ & 0.592 & \multirow[t]{4}{*}{0.679} \\
\hline & $\rightarrow \quad \mathrm{CV} 2$ & 0.588 & \\
\hline & $\rightarrow \quad \mathrm{CV} 3$ & 0.665 & \\
\hline & $\rightarrow \quad \mathrm{CV} 4$ & 0.550 & \\
\hline \multirow[t]{5}{*}{ Kepuasan } & $\rightarrow \mathrm{S} 1$ & 0.521 & \multirow[t]{5}{*}{0.770} \\
\hline & $\rightarrow \quad \mathrm{S} 2$ & 0.632 & \\
\hline & $\rightarrow \quad \mathrm{S} 3$ & 0.567 & \\
\hline & $\rightarrow \quad \mathrm{S} 4$ & 0.562 & \\
\hline & $\rightarrow \quad \mathrm{S} 5$ & 0.598 & \\
\hline
\end{tabular}

\section{Evaluasi Model Penelitian}

Kami melakukan analisis struktur kovarian menggunakan perangkat lunak AMOS untuk menguji hipotesis. Ukuran keseluruhan goodness-of-fit untuk model penelitian ditunjukkan pada Tabel 4. Pengukuran kesesuaian absolut yaitu dengan mengevaluasi Chi-square, GFI (Goodness of Fit Index), RMR (Root Mean square Residual), dan RMSEA (Root Mean Square Kesalahan Perkiraan). Pengukuran kesesuaian inkremental yaitu dengan mengevaluasi kesesuaian model penelitian melalui NFI (Normed Fit Index), CFI (Comparative Fit Index), dan TLI (Turker - Lewis Index). Pengukuran kesesuaian parsimous yaitu dengan mengevaluasi tingkat kesesuaian model penelitian melalui NC (Normed Chi-square). 
Tabel 4. Hasil Pengujian Goodness-of-fit Model

\begin{tabular}{|l|l|l|l|}
\hline \multicolumn{1}{|c|}{ Indeks } & \multicolumn{1}{c|}{ Nilai Kritis } & \multicolumn{1}{c|}{ Hasil } & Evaluasi Model \\
\hline Chi Square & Semakin kecil semakin baik & $397.396(\mathrm{p}=0.000)$ & Fit \\
\hline CMIN/DF & $<2.00$ & 1.958 & Fit \\
\hline CFI & $\geq 0.95$ & 0.914 & Marginal \\
\hline RMSEA & $\leq 0.08$ & 0.069 & Fit \\
\hline TLI & $\geq 0.90$ & 0.903 & Fit \\
\hline GFI & $\geq 0.90$ & 0.847 & Marginal \\
\hline AGFI & $\geq 0.90$ & 0.809 & Marginal \\
\hline NFI & $\geq 0.90$ & 0.840 & Marginal \\
\hline PCFI & $>0.6$ & 0.803 & Fit \\
\hline
\end{tabular}

Berdasarkan tabel di atas dilihat bahwa nilai Chi Square adalah 397.396 dengan level probabilitas 0.000, Menurut Hair et al. (2010) untuk jumlah sampel <250 dengan Probability value yang signifikan termasuk dalam good fit, eavaluasi model pada penelitian ini adalah fit. CMIN/DF sebesar 1.948 kecil dari 2.00 maka kesimpulan evaluasi model adalah fit. Nilai CFI adalah 0.914 mendekati 0.95 maka kesimpulan evaluasi model adalah marginal. Nilai RMSEA adalah 0.069 lebih kecil dari 0.08 maka kesimpulan evaluasi model adalah fit. Nilai TLI adalah 0.903 besar dari 0.90 , maka kesimpulan evaluasi model adalah fit. Nilai GFI adalah 0.847 mendekati 0.90, maka kesimpulan evaluasi model adalah marginal. Nilai AGFI adalah 0.810 mendekati 0.90, maka kesimpulan evaluasi model adalah marginal. Nilai NFI adalah 0.840 mendekati 0.90, maka kesimpulan evaluasi model adalah marginal, dan nilai PCFI adalah 0.807 besar dari 0.6, maka kesimpulan evaluasi model adalah fit.

Berdasarkan penjelasan diatas dapat disimpulkan bahwa model dalam penelitian ini sudah fit, angka pada beberapa kriteria sudah mendekati karakteristik fit, jadi model dalam penelitian ini layak untuk digunakan.

\section{Pengujian Hipotesis}

Kriteria goodness of fit model structural yang diestimasi dapat terpenuhi, maka tahap selanjutnya adalah analisis terhadap hubungan structural model (pengujian hipotesis). Hubungan antar konstruk dalam hipotesis ditunjukkan oleh nilai regression weights (Hair et al., 2010). Untuk menganalisis lebih jelas mengenai pengaruh kesadaran merek, citra merek, nilai pelanggan, dan kepuasan terhadap loyalitas merek produk teh kemasan, dapat dilihat pada tabel dibawah ini:

Tabel 5. Pengaruh langsung antar variabel

\begin{tabular}{|l|l|l|l|l|}
\hline Hipotesis & Estimate & S.E. & C.R. & P \\
\hline H1. Kesadaran merek $\rightarrow$ citra merek & 1.094 & 0.139 & 7.889 & 0.000 \\
\hline H2. Citra merek $\rightarrow$ nilai pelanggan & 1.307 & 0.157 & 8.305 & 0.000 \\
\hline H3. Nilai pelanggan $\rightarrow$ Kepuasan & 0.154 & 0.037 & 4.214 & 0.000 \\
\hline H4. Citra merek $\rightarrow$ Kepuasan & 0.617 & 0.096 & 6.452 & 0.000 \\
\hline H5. Kepuasan $\rightarrow$ loyalitas merek & 1.160 & 0.163 & 7.099 & 0.000 \\
\hline
\end{tabular}

Dalam mendapatkan pemahaman mengenai hubungan antar variabel, kami menguji pengaruh tidak langsung dengan menggunakan uji sobel. Hasil penghitungan Sobel Test dapat dilihat pada tabel berikut:

Tabel 6. Pengaruh tidak lengsung dengan uji sobel

\begin{tabular}{|l|l|l|l|}
\hline Pengaruh & $t$ value & S.E. & $P$ value \\
\hline Citra merek $\rightarrow$ kepuasan $\rightarrow$ loyalitas merek & 3.494 & 0.027 & 0.000 \\
\hline Nilai pelanggan $\rightarrow$ kepuasan $\rightarrow$ loyalitas merek & 3.593 & 0.050 & 0.000 \\
\hline
\end{tabular}

Hasil Sobel Test pertama 3.493 ( $\mathrm{p}<0.05)$, nilai sobel test yang signifikan artinya kepuasan berperan sebagai mediator pada pengaruh citra merek dengan loyalitas merek. Citra merek sangat mendukung 
kepuasan pelanggan. Sedangkan kepuasan pelanggan akan membentuk loyalitas merek. Hasil penelitian ini menunjukkan bahwa citra merek akan mempengaruhi loyalitas merek apabila pelanggan merasa puas. Hasil Sobel Test kedua adalah $3.593(\mathrm{p}<0.05)$ artinya Kepuasan berperan sebagai mediator pada pengaruh nilai pelanggan dengan loyalitas merek. dapat disimpulkan bahwa nilai pelanggan akan mempengaruhi loyalitas merek apabila pelanggan merasa puas.

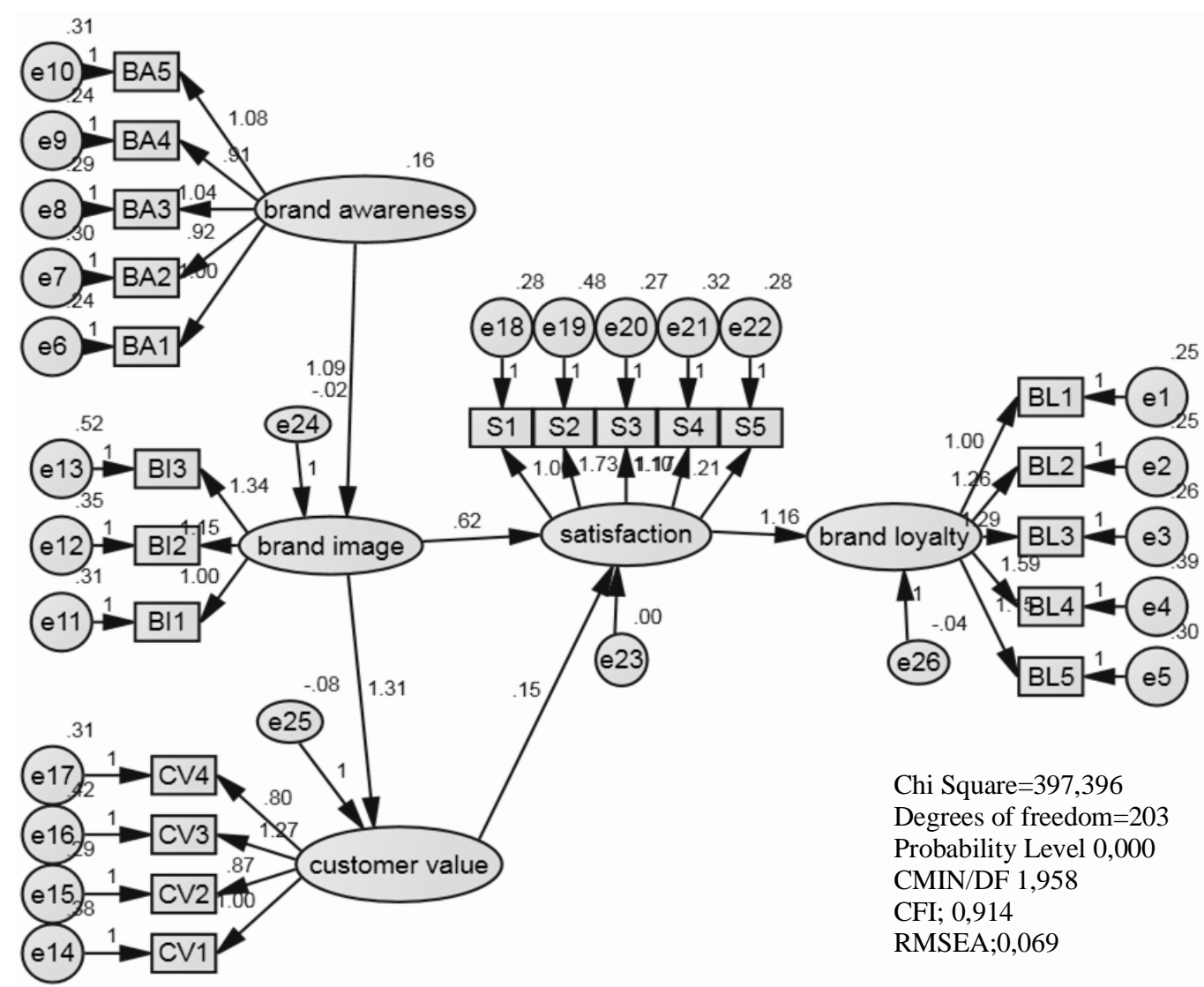

Gambar 1 Model hasil penelitian

Kesadaran merek berpengaruh signifikan dan positif terhadap citra merek. Hal ini dibuktikan dari hasil perhitungan dengan Structual Equation Modeling dengan Amos 18 terdapat nilai CR sebesar 7.889 $(\mathrm{p}=0,000 \leq 0,05)$. Artinya semakin tinggi tingkat kesadaran pelanggan akan merek maka citra merek akan semakin meningkat atau positif. Beberapa penelitian terdahulu mengatakan bahwa kesadaran merek berpengaruh positif dan signifikan terhadap citra merek (Mulyono, 2016). Kesadaran merek sangat penting untuk membentuk citra merek, karena jika merek sudah mapan di ingatan pelanggan maka lebih mudah untuk menciptakan asosiasi asosiasi merek (Esch et al., 2006). Begitupun dalam produk teh kemasan. Jika suatu merek teh kemasan sudah berada diingatan pelanggan maka akan dengan mudah untuk meningkatkan kesadaran pelanggan akan satu merek teh kemasan. Hasil ini memberikan bukti bahwa dalam menigkatkan citra merek produk teh kemasan, perusahaan teh kemasan dapat meningkatkan kesadaran merek seperti dengan melakukan berbagaimacam strategi promosi sehingga satu produk teh kemasan dapat menjadi top of mind konsumen.

Citra merek berpengaruh signifikan dan positif terhadap nilai pelanggan. Hal ini dibuktikan dari hasil perhitungan dengan model struktural equation modelling menggunakan Amos, diperoleh nilai CR sebesar $8.305(\mathrm{p}=0,000 \leq 0,05)$. Artinya semakin tinggi tingkat citra merek maka nilai pelanggan akan semakin meningkat. Hasil penelitian ini sejalan dengan beberapa penelitian terdahulu (Glynn \& Woodside, 2009; Rahi, 2016). Citra merek yang positif akan meningkatkan nilai pelanggan. Jika citra merek produk teh kemasan dipersepsikan positif oleh pelanggan maka nilai pelanggan akan meningkat. Dapat dikatakan bahwa untuk meningkatkan nilai pelanggan perlu memperhatikan citra merek. Dalam produk teh kemasan, perusahaan yang mampu membentuk citra merek positif di benak konsumen akan memberikan manfaat tambahan bagi produk teh kemasan tersebut. Sehingga, jika manfaat yang 
didapatkan konsumen lebih dari pengorbanan yang dikeluarkan konsumen maka dapat memnberikan nilai pelanggan yang positif.

Nilai pelanggan berpengaruh signifikan dan positif terhadap kepuasan pelanggan. Hasil nilai CR sebesar $4.214(\mathrm{p}=0,000 \leq 0,05)$ maka nilai pelanggan berpengaruh signifikan dan positif terhadap Kepuasan. Hasil pengujian ini juga didukung oleh beberapa penelitian terdahulu yang relevan (Ariff et al., 2012; Onaran et al., 2013). Jika perusahaan mampu menciptakan nilai pelanggan yang tinggi, ini akan mengarakan kepada faktor emosional positif konsumen (Rafdinal \& Suhartanto, 2020). Semakin tinggi nilai yang dipersepsikan oleh pelanggan akan meningkatkan kepuasan pelanggan akan suatu merek. Pelanggan akan merasa puas apabila nilai yang dijanjikan sesuai dengan harapannya. Pada saat pelanggan merasakan manfaat yang lebih, pada saat itu pelanggan akan merasa puas dan berniat untuk membeli kembali dimasa yang akan datang. Bagitupun dengan konsumen produk teh kemasan, jika perusahaan teh kemasan mampu memberikan nilai pelanggan yang positif maka dapat menciptakan kepuasan konsumen produk teh kemasan.

Pengaruh antara citra merek dengan kepuasan terdapat nilai CR sebesar $6.452 \quad(p=0,000 \leq 0,05)$ maka citra merek berpengaruh signifikan dan positif terhadap kepuasan. Hasil penelitian ini didukung oleh beberapa penelitian terdahulu (Dunuwille \& Pathmini, 2016; Upamannyu \& Sankpal, 2014). Berdasarkan penjelasan diatas dapat disimpulkan bahwa ada hubungan yang positif antara citra merek dan kepuasan. Citra yang positif pada merek teh kemasan akan meningkatkan kepuasan pelanggan. Suatu produk teh kemasan yang telah memiliki citra merek positif di benak konsumen akan membuat konsumen dengan senang hati untuk mengkonsumsinya. Hal ini berkaitan dengan emosional konsumen yang telah menganggap suatu produk teh kemasan sebagai pilihan utama mereka karena citra yang sudah terbentuk dibenak mereka. Jika perusahaan mampu memenuhi persepsi konsumen dengan memberikan produk yang berkualitas dan terus membentuk citra positif, maka dapat membuat mereka puas.

Pengaruh antara kepuasan dengan loyalitas merek terdapat nilai CR sebesar $7.099(\mathrm{p}=0,000 \leq 0,05)$. Hal ini menjelaskan bahwa ada pengaruh yang signifikan dan positif dari kepuasan terhadap loyalitas merek, yang berarti semakin tinggi kepuasan pelanggan maka tingkat loyalitas merek akan semakin tinggi pula. Hasil ini sejalan dengan penelitian terdahulu (Fusva et al., 2020; Leo et al., 2020; Mulyono, 2016). Kepuasan sangat penting untuk meningkatkan loyalitas pelanggan. Pada saat pelanggan sudah merasakan kepuasan, pelanggan akan berniat untuk melakukan pembelian secara terus menerus, tidak berpindah ke merek lain dan tetap setia dengan merek produk teh kemasan tertentu.

Pada pengaruh tidak langsung, terdapat pengaruh tidak langsung antara variabel citra merek dengan loyalitas merek, Kepuasan berperan sebagai mediator pada pengaruh citra merek dengan loyalitas merek. Hasil pengujian mediasi ini didukung oleh penelitian terdahulu (Fusva et al., 2020; Ghafoor et al., 2012; Mulyono, 2016; Tu \& Chang, 2012). Citra merek dapat mempengaruhi loyalitas merek melalui kepuasan. Jika suatu merek telah memberikan citra yang positif bagi pelanggan, maka pelanggan akan merasa puas dan secara tidak langsung akan meningkatkan loyalitas merek. Kepuasan juga menjadi pemediasi pada pengaruh nilai pelanggan terhadap loyalitas merek. Pelanggan yang mempersepsikan nilai positif atas suatu merek, artinya pelanggan tersebut sudah merasa puas dengan merek yang dikonsumsinya. Pelanggan yang merasa puas akan meningkatkan loyalitasnya atas merek yang dikonsumsinya. Hasil penelitian ini sejalan dengan penelitian terdahulu (Ghafoor et al., 2012; Igaua et al., 2013). Pelanggan yang sudah merasakan nilai yang positif, maka pelanggan merasa puas dengan merek, kemudian akan terciptanya loyalitas merek yang tinggi.

\section{Kesimpulan}

Hasil penelitian mendukung semua hipotesis yang diajukan. Hasil pengaruh langsung menunjukan bahwa kesadaran merek berpengaruh signifikan terhadap citra merek, citra merek berpengaruh signifikan terhadap nilai pelanggan, Nilai pelanggan dan citra merek berpengaruh signifikan terhadap kepuasan, citra merek berpengaruh signifikan terhadap kepuasan, dan kepuasan berpengaruh signifikan terhadap loyalitas merek. Hasil penelitian ini memberikan pengetahuan bahwa kepuasan, nilai pelanggan, citra merek, dan kesadaran merek merupakan faktor penting dalam mempengaruhi loyalitas merek khusus pada produk teh kemasan. 


\section{Daftar Pustaka}

Aaker, D. A. (2013). Manajemen pemasaran strategis. Edisi Kedelapan. Salemba Empat. Jakarta.

Ariff, M. S. B. M., Fen, H. S., \& Ismail, K. (2012). Relationship between customers' perceived values, satisfaction and loyalty of mobile phone users. Review of Integrative Business and Economics Research, 1(1), 126.

Award, T. B. (2019). Data market share dan top brand indeks kategori makanan dan minuman (online). Www.Topbrand-Award.Com. https://www.topbrand-award.com/en/top-brand-index-int/

Christopher Lovelock, J. W. (2012). Services marketing: people, technology, strategy. Nw Delhi: Pearson Education.

Dunuwille, V. M., \& Pathmini, M. G. S. (2016). Brand image and customer satisfaction in mobile phone market: study based on customers in Kandy district. Journal of Business Studies, 3(1), 1-13.

Esch, F., Langner, T., Schmitt, B. H., \& Geus, P. (2006). Are brands forever? How brand knowledge and relationships affect current and future purchases. Journal of Product \& Brand Management.

Fusva, A., Dean, D., Suhartanto, D., Syarief, M. E., Arifin, A. Z., Suhaeni, T., \& Rafdinal, W. (2020). Loyalty formation and its impact on financial performance of Islamic banks - evidence from Indonesia. Journal of Islamic Marketing. https://doi.org/10.1108/JIMA-12-2019-0258

Ghafoor, M. M., Iqbal, H. K., Tariq, U., \& Murtaza, F. (2012). Impact of customer satisfaction and brand image on brand loyalty. Progress in Business Innovation \& Technology Management, 2(2), 69-77.

Glynn, M. S., \& Woodside, A. G. (2009). Business-to-business brand management. Emerald group publishing.

Hair, J. F., Anderson, R. E., Babin, B. J., \& Black, W. C. (2010). Multivariate data analysis: A global perspective (Vol. 7). Upper Saddle River, NJ: Pearson.

Hair, J. F., Black, W. C., Babin, B. J., Anderson, R. E., \& Tatham, R. L. (1998). Multivariate data analysis (Vol. 5, Issue 3). Prentice hall Upper Saddle River, NJ.

Hanzaee, K. H., \& Norouzi, A. (2012). Customer value scale development: Merchandise and differentiation value. African Journal of Business Management, 6(22), 6652-6657.

Hasan, H. F. A., Ilias, A., Rahman, R. A., \& Razak, M. Z. A. (2008). Service quality and student satisfaction: A case study at private higher education institutions. International Business Research, $1(3), 163-175$.

Igaua, O. A., Kassima, A. W. B. M., Al-Swidib, A. K., Haruna, A. Bin, \& Shamsudinc, A. S. Bin. (2013). The effect of perceived value on brand loyalty and mediated by customer satisfaction: A case of hand phone users.

Jorfi, S., \& Gayem, A. (2016). Brand equity, brand loyalty and consumer satisfaction (case study consumer goods of brand Samsung in shops of Khuzestan). International Journal of Humanities and Cultural Studies (IJHCS) ISSN 2356-5926, 1(1).

Kocoglu, C., Tengilimoglu, D., Ekiyor, A., \& Guzel, A. (2015). The effects of brand loyalty on the consumer buying behaviors: The example of perfume in the province of Ankara. International Journal of Humanities and Management Sciences, 3(5), 318-323.

Leo, G., Brien, A., Astor, Y., Najib, M., Novianti, S., Rafdinal, W., \& Suhartanto, D. (2020). Attraction loyalty, destination loyalty, and motivation: agritourist perspective. Current Issues in Tourism, 113. https://doi.org/10.1080/13683500.2020.1772207

Mao, J. (2010). Customer brand loyalty. International Journal of Business and Management, 5(7), 213.

Martisiute, S., Vilutyte, G., \& Grundey, D. (2010). Product or brand? how interrelationship between customer satisfaction and customer loyalty work. European Journal of Interdisciplinary Studies, 2(1), 5 .

Mowen, J. C., \& Minor, M. (2002). Perilaku Konsumen. Alih Bahasa: Dwi Kartini. Edisi 5jilid 1. In $P T$. Erlangga. Erlangga.

Mulyono, H. (2016). Brand awareness and brand image of decision making on university. Jurnal Manajemen Dan Kewirausahaan, 18(2), 163-173.

Nunnally, J. C. (1978). Psychometric Theory: $2 d$ Ed. McGraw-Hill.

Onaran, B., Bulut, Z. A., \& Ozmen, A. (2013). A study to investigate the effect of customer value on customer satisfaction, brand loyalty and customer relationship management performance. Business and Economics Research Journal, 4(2), 1-37. 
Peter, J., \& Olson, J. C. (2000). Perilaku kosumen dan strategi pemasaran. In Erlangga (Vol. 2). Erlangga.

Rafdinal, W., \& Suhartanto, D. (2020). Loyalty model for ethnic restaurants : The role of quality and value. 2(2), 123-138. https://doi.org/10.35313/ijabr.v0i0.104

Rahi, S. (2016). Impact of customer value, public relations perception and brand image on customer loyalty in services sector of Pakistan. Arabian J Bus Manag Review S, 2(2).

Shahroudi, K., \& Naimi, S. S. (2014). The impact of brand image on customer satisfaction and loyalty intention (case study: consumer of hygiene products). International Journal of Engineering Innovations and Research, 3(1), 57.

Suki, J., \& Sasmita, J. (2015). Young consumers' insights on brand equity: Effects of brand association, brand loyalty, brand awareness, and brand image. International Journal of Retail \& Distribution Management, 43(3), 276-292.

Torres-Moraga, E., Vásquez-Parraga, A. Z., \& Zamora-González, J. (2008). Customer satisfaction and loyalty: start with the product, culminate with the brand. Journal of Consumer Marketing.

Tu, Y.-T., \& Chang, H.-C. (2012). Corporate brand image and customer satisfaction on loyalty: An empirical study of Starbucks coffee in Taiwan. Journal of Social and Development Sciences, 3(1), 24-32.

Upamannyu, N. K., \& Sankpal, S. (2014). Effect of brand image on customer satisfaction \& loyalty intention and the role of customer satisfaction between brand image and loyalty intention. Journal of Social Science Research, 3(2), 274-285.

\section{*Email korespondensi:}

Wahyu Rafdinal

wahyu.rafdinal@polban.ac.id 